\title{
Success purpose tendencies Lise öğrencilerinin başarı of high school students
}

\author{
İlker Kösterelioğlu ${ }^{2}$ \\ Ümit Çelen ${ }^{3}$ \\ Meltem Akın Kösterelioğlu ${ }^{4}$ \\ Rasim Ahıska ${ }^{5}$
}

\begin{abstract}
The aim of this research is to investigate success purpose tendencies of high school students related to the high school type variable. The data was obtained through a developed questionaire for 796 students attending different high schools in Amasya and 2x2 Achievement Goals Questionnaires. For the analyses of the data ttest, one-way variance analysis and (LSD) test to determine the differerence among the groups in the variance analysis and ki-square test were used. Furthermore, descriptive statistical scores that the students got from the scale were presented. When the averages investigated, it is seen that learning approach sub-scale average scores are the highest and performance avoidance average scores are the lowest. It is found out that female students have higher average scores related to learning approach and learning avoidance sub-scale whereas the male students have higher average scores in performance approach and performance avoidance sub-scale. There has seen no difference in the class level success purpose tendency average scores of the students related to the class levels. When the scores of the
\end{abstract}

\section{Özet}

$\mathrm{Bu}$ araştırmanın amacı öğrencilerin başarı amaç yönelimlerini lise türü değişkeni açısından incelemektir. Veriler Amasya ilindeki farklı liselerde öğrenim gören 796 öğrenciden geliştirilen anket formu ve 2x2 Başarı Amaç Yönelimi Ölçeği aracilığıyla toplanmıştır. Verilerin analizinde t-testi, tek yönlü varyans analizi ve varyans analizinde farklı bulunan grupların tespiti için asgari önemli fark (LSD) testi ve ki-kare testi kullanılmıştur. Ayrıca öğrencilerin ölçekten aldıkları puanların tanımlayıc1 istatistikleri sunulmuştur. Ortalamalar incelendiğinde öğrenme yaklaşma alt ölçeği puan ortalamasının en yüksek, performans kaçınma alt ölçeği puan ortalamasının ise en düşük olduğu saptanmıştır. Öğrenme yaklaşma ve öğrenme kaçınma alt ölçeklerinde kızların, performans yaklaşma ve performans kaçınma alt ölçeklerinde ise erkeklerin puan ortalaması daha yüksek olduğu belirlenmiştir. Öğrencilerin sınıf düzeyleri başarı amaç yönelimi puan ortalamaları sınıf düzeyine göre farklılık elde edilmemiştir. Öğrencilerin lise türüne göre puanları incelendiğinde öğrenme kaçınma alt ölçeği puan ortalamalarının lise

\footnotetext{
${ }^{1} \mathrm{Bu}$ araştırma Amasya Üniversitesi SEB-BAP 17-154 nolu oraoje kapsamında desteklenen projeden üretilmiştir ve 18-21 Mayıs 2017 tarihleri arasında Macaristan'da düenlenen ERPA Congress'te sözlü bildiri olarak sunulmuştur.

${ }^{2}$ Doc. Dr., Amasya Üniversitesi Eğitim Fakültesi Eğitim Bilimleri Bölümü, ikostereli@gmail.com

${ }^{3}$ Dr. Öğr. Üyesi., Amasya Üniversitesi Eğitim Fakültesi Eğitim Bilimleri Bölümü, umitcelen@yahoo.com

${ }^{4}$ Doc. Dr., Amasya Üniversitesi Eğitim Fakültesi Eğitim Bilimleri Bölümü, mkostereli@hotmail.com

5 Öğr. Gör., Amasya Üniversitesi Eğitim Fakültesi Eğitim İlköğretim Bölümü, rasim.ahiska@gmail.com
} 

Journal of Human Sciences, 16(2), 662-678, doi: 10.14687/ihs.v16i2.5603

students related to the high school type investigated, there has seen no difference in the learning avoidance sub-scale average scores regarding to the type of school. However, there is a statistically difference in the average scores of the other sub-scale. There is a meaningful relationship between the success perception of the students and success purpose tendency subscale in which the students got the highest scores. The adoption in the the percentage of learning approach tendency of the students who accept themselves partially successful is higher than the percentage of learning approach tendency of the students who see themselves partially unsuccessful.The adoption in the the percentage of learning avoidance and performance avoidance tendency of the students who accept themselves partially unsuccessful is higher than the percentage of the performance approach tendency of the students who see themselves unsuccessful.

Keywords: Success; success purpose tendency; high school students; approach; avoidance; performance.

(Extended English summary is at the end of this document) türüne göre farklllık göstermediği; diğer alt ölçek puan ortalamalarnnda ise istatistiksel olarak anlamlı şekilde farklilık bulunduğu belirlenmiştir. Öğrencilerin başarı algılarıla en yüksek puan aldıkları başarı amaç yönelimi alt ölçeği arasında istatistiksel olarak anlamlı bir ilişki olduğu saptanmıştır. Kendini kısmen başarilı ve başarılı gören öğrencilerin öğrenme yaklaşma yönelimini benimseme yüzdesi kısmen başarısız ve başarısız görenlerden fazladır. Kısmen başarısız öğrencilerde öğrenme kaçınma ve performans kaçınma yönelimini benimseme yüzdesi, başarısız gören öğrencilerde ise performans yaklaşma yönelimini benimseyen öğrenci yüzdesi diğerlerinden fazladır.

Anahtar Kelimeler: Başarı; başarı amaç yönelimi; lise öğrencileri; yaklaşma; kaçınma; performans.

\section{Giriş}

Öğretim sürecinin niteliğini artıran önemli değişkenlerden birisi öğrenciler için hazırlanan etkinliklere öğrencilerin katılım düzeyleridir. Eğitimin tarihi süreci içinde sıklıkla vurgulanan öğrenme ilkelerinden birisi öğrenenlerin öğrenme sürecine etkin biçimde katıllım göstermelerinin başarıya katkı sağlayacağı yönündedir. Öğrenenin öğrenme sürecinde etkin katılım göstermesinin yanında beklenti ve hedeflerinin de dikkate alınması önemlidir.

Öğretim faaliyetlerinin amacı dersin programında belirlenen hedeflerine ulaşmaktır. Öğrenme hedeflerine ulaşılması başarı kavramıyla özdeşleşmiştir. Öğrenciler başarıya ulaşmak için farklı yollar izlemektedirler. Öğrencilerin bu amaçla başvurdukları yolları açılamaya çalışan teorilerden birisi başarı amaç teorisidir. Başarı amaç teorisi, öğrencilerin başarılı olmak için hangi yolları neden izledikleri ile ilgilenir (Kaplan ve Maehr, 1999). Başarı amaç teoirisi, başarı kavramına odaklanmakla birlikte öğrencilerin öğrenme ile ilgili olarak derse kattlım, okulu bırakma, devamsızlık yapma veya öğrenmeyi değerli bulma gibi okula ilişkin olumlu ya da olumsuz davranışlarını açıklamaya odaklanmaktadır (Schunk, Pintrich ve Meece, 2008). Bu teori başarmak için bir görevle karşı karşıya kaldığında öğrenenin, bu görev doğrultusunda hedeflerini belirlemeye ve öğrenenin öğrenme görevleriyle meşgul olma nedenlerini açıklamaya çalışan sosyobilişsel bir teoridir (Middleton, Kaplan ve Midgley, 2004; Murayama, Elliot ve Yamagata, 2011, Özgüngör, 2003).

Alanyazın incelendiğinde öğrenenlerin, temelde öğrenme hedef yönelimi (mastery goal approach) ve performans hedef yönelimi (performance goal approach) olmak üzere iki yönelimi tercih ettikleri vurgulanmaktadır (Ames ve Archer, 1988; Elliot ve McGregor, 2001). Klasik başarı 
amaç modeli olarak adlandırılan bu modelde öğrenme hedef yönelimi öğrencilerin öğrenme, anlayış kazanma ve kendini geliştirmelerine odaklanırken performans hedef yönelimi öğrencilerin diğer öğrenenlere karşı daha fazla yetenekli görünmelerine odaklanır (Agbuga and Xiang, 2008). Öğrenenin, öğrenme hedef yönelimi, olumlu bir tutum olarak kabul edilmektedir. Bu yönelime sahip öğrenenler yeteneklerini arttırmakta istekli ve kendi kendilerini sürekli geliştirme arzusundadırlar. Öğrenme hedefleri onlar için daha fazla öğrenme, onları motive etme ve belli kavramları öğrenme, gelişim sağlama, bir öğrenmeyi tamamlamada kendi kendine zorlukların üstesinden gelmek için çaba göstermeyi ifade etmektedir (Pintrich, 2000). Öğrenme yönelimli öğrenciler, bilgilerini geliştirme ve yeni beceriler geliştirmeye odaklanır (Albaili, 1998). Başka bir söylemle bu öğrenciler bilgiyi içselleştirme ve yeterlik geliştirmeye karşı içsel motivasyon taşımaktadırlar (Rawsthorne ve Elliot, 1999).

Performans hedef yönelimli öğrenciler öncelikli olarak diğer arkadaşlarına karşı daha iyi görünmek amacıyla yeteneklerini göstermekle ya da algılanan yeteneğindeki eksikliği gizlemeyle ilgilenirler (Ames, 1992). Bu yönelime sahip kişiler olumsuz değerlendirmelere maruz kalmamak için zorlu görevlerden kaçınma eğilimi gösterirler ve öğrenmek için motivasyonları daha düşüktür. Öğrenciler yetenekleri üzerine odaklanır ve yeteneksiz olarak görüleceklerini düşündüklerinde kolaylıkla görevden vazgeçme davranışı sergilerler (Dweck ve Leggett, 1988). Performans hedef yönelimli öğrenciler sosyal karşılaştırmaları dikkate alarak performanslarıyla ilgili olumsuz dönüt almaktan kaçınırlar (Elliot, 1999). Bu öğrencilerin motivasyon kaynakları daha çok dışsal kaynaklardır. Kısaca, öğrenme amaç yönelimi ilgi, öğrenme, yoğun çaba gösterme, kendi ile yarışma hali ve diğer değişkenlere karşı olumlu duygular besleme ile ilgiliyken; performans amaç yönelimi daha çok başarının yeteneğe dayalı olduğu, başkalarıyla yarış halinde olduğunu göz önüne alarak başarının buna göre anlamlandırıldığı ve az çaba ile başarıya ulaşılabileceği inancını temsil etmektedir (A ̆̆buğa, 2014).

Tablo 1. Başarı Amaç Yönelimleri Yaklaşma ve Kaçınma Durumları (Pintrich, 2000)

\begin{tabular}{|c|c|c|}
\hline Başarı & Kaçınma Durumu & Yaklaşma Durumu \\
\hline \multirow[b]{2}{*}{$\begin{array}{l}\text { Öğrenme } \\
\text { Amaçları }\end{array}$} & $\begin{array}{l}\text { Yanlış anlamaktan, öğrenememek ve } \\
\text { görevi başaramamaktan kaçınma }\end{array}$ & $\begin{array}{l}\text { Görevi başarma, öğrenme ve anlamaya } \\
\text { yoğunlaşma }\end{array}$ \\
\hline & $\begin{array}{l}\text { Doğru standartlar belirleme ve bu } \\
\text { standartları göreve bağlı olarak yanlış } \\
\text { kullanmaktan kaçınma }\end{array}$ & $\begin{array}{l}\text { Kendini geliştirmek için standartlar } \\
\text { belirleme, ilerleme ve görevi } \\
\text { derinlemesine anlama }\end{array}$ \\
\hline \multirow{2}{*}{$\begin{array}{l}\text { Performans } \\
\text { Amaçlar1 }\end{array}$} & $\begin{array}{l}\text { Aşağılanmaktan kaçınma, başkalarıyla } \\
\text { karşılaş̧trıldığında aptal gibi } \\
\text { görünmemeye çalışma }\end{array}$ & $\begin{array}{l}\text { Zeki görünmeye ve görevde } \\
\text { başkalarıyla karşılaştırıldığında en iyi } \\
\text { olmaya çalışma }\end{array}$ \\
\hline & $\begin{array}{l}\text { En düşük puanları almamak, sınıfin en } \\
\text { kötüsü olmamak gibi normatif } \\
\text { standartlar kullanma }\end{array}$ & $\begin{array}{l}\text { En yüksek puanları almak, sınıfin en } \\
\text { iyisi olmak gibi normatif standartlar } \\
\text { kullanma }\end{array}$ \\
\hline
\end{tabular}

Özellikle 1990’lı yıllarda araştırmacılar öğrenme hedef yönelimi ve performans hedef yöneliminin öğrencilerin başarı ya da başarısızlıklarını açılklamada yeterli olmadığını düşünerek Üçlü Başarı Modeli'ni (Elliot, 1999; Elliot ve Church, 1997; Elliot ve Harackiewicz, 1996) ve ardından da 2x2 Başarı Hedef Modeli'ni (Conroy, Elliot ve Hofer, 2003; Elliot, 1999; Elliot ve McGregor, 2001) geliştirilmişdir. Bu araştırmanın da konusunu teşkil eden 2x2 Başarı Amaç Yönelimi’nde öğrenme hedef yönelimi ve performans hedef yönelimi kendi içerisinde yaklaşma ve kaçınma durumu olarak dört faktörlü bir yapıda ele alınmıştır.

Öğrenme amaç yönelimine sahip bireyler çaba göstermenin beceri edinmeyi artırdığına inanırlar ve kendi gelişimlerini belirleyebilmek için geçmiş performansıyla şimdikini karşılaştırma yoluna giderler (Schunk, 1996). Öğrenme amaç yönelimi bir bireyin öğrenilmesi gereken konu ile ilgili tam anlamıyla öğrenme isteği durumu olarak tanımlanmakta ve bu yönelimin bireylerin öğrenme 
sürecindeki gösterdikleri çabayı arttırdığını, bireylerin daha iyi bir gelişim için kendilerini değerlerdirmelerine yardımcı olduğu ifade edilmektedir (Schunk, 1996). Öğrenme-amaç yönelimli bireylerin öğrenme süreçlerinde içsel motivasyonları ile harekete geçtiği, öğrenilmesi gereken konu ile ilgili; olumlu başarı davranışları sergileme, öğrenme için çaba gösterme, orta düzey zorluktaki aktivilere yönelme, içsel motivasyonla performansını geliştirme ve başarısızlık durumunda da yeniden motive olup çalışmaya devam etme şeklinde olumlu tutum ve davranışlar sergilediği söylenebilir (Lemyre, Roberts ve Ommundsen, 2002). Elliot ve Harackiewicz (1996) de bireylerin sahip olduklar1 öğrenme amaçlarının içsel motivasyonlarına olumlu yönde etki ettiğini ifade etmiştir. Pajares ve Cheong'a (2003) göre, bir öğrenci herhangi bir öğrenme sürecinde söz konusu bilgiyi eksiksiz öğrenmeyi amaçlıyor, her açıdan konuya hâkimiyet kurmayı hedefliyorsa öğrenme-amaç yöneliminde olduğunu göstermektedir. Bu doğrultuda, Meece, Blumenfeld ve Hoyle (1988) öğrenme amaç yönelimli bireylerin başanı elde etmek amacı ile bilişsel olarak daha aktif olduklarını, algılanan yeteneklerinin öğrenme sürecinde yeterli düzeyde olduğunu düşünerek içsel olarak motive olduklarını ifade etmişlerdir. Ames (1992) göre de, öğrenme amaç yönelimli öğrenciler kendi istekleri doğrultusunda görev belirleyerek kendi yetenekleri doğrultusunda standartlar oluştururlar. Elliot ve Harackiewicz (1996) öğrenme amaçlarının içsel motivasyonu artırdığını belirtmişlerdir. Yapılan çalışmalarda, öğrenme-amaç yönelimli bireylerin öğrenmeye karşı motivasyon sahibi, performansamaç yönelimli bireylerin ise öğrenmeye karşı negatif tutumlara sahip olduğu ifade edilmektedir (Pajares ve Cheong, 2003). Green ve Miller (1996) araştırmalarında akademik başarının yetenek ve öğrenme amaç yönelimi ile pozitif yönde ilişkili olduğunu, algilanan yetenek ve amaç yöneliminin bilişsel çaba ile doğrudan, akademik başarı ile dolaylı olarak ilişkili olduğunu tespit etmişlerdir.

Performans amaç yönelimi içinde kaçınma durumunda olan öğrenciler için başkaları tarafından iyi değerlendirilmek çok önemlidir ve bu öğrenciler olumsuz yargılanmaktan kaçınırlar (Finney, Pieper ve Barron, 2004). İçinde bulundukları dışsal motivasyonun etkisiyle hata yaptıklarında bu durumu başarısızlık işareti olarak tanımladıklarından devam ettikleri çalışmayı kolayca bırakabilirler. $\mathrm{Bu}$ bireyler zor durumlarla yüzleşmekten kaçınır; yetenekli ve yeterli görünmeye özen gösterir, başarı elde etmek veya başarısızlıktan kaçınmak için çaba harcayarak diğer insanlarda bir izlenim oluşturmayı amaçlarlar (Green ve Miller, 1996). Çünkü hedef başkalarına göre daha başarısız görünmek gibi olumsuz olasilıklardan uzaklaşmaktır (Elliot, 2005). Performans amaç yöneliminin yaklaşma biçiminde ise öğrenciler, sınıfın en iyisi olmayı, arkadaşlarıyla karşılaştırılınca daima sınıfta en iyi performansı gösteren, en yüksek notları alan kişi olmayı ve öğrenmekten ziyade başarılı görünmeyi amaçlarlar (Pintrich, 2000). Performans yaklaşmada kendisini başkalarına karşı akademik anlamda üstünlük kanıtlama çabası (Özgüngör, 2014), performans kaçınmada ise başkalarına karşı akademik anlamda zayıf görünmekten kaçınma durumu (Finney, Pieper ve Barron, 2004) söz konusudur. Performans yaklaşıml öğrenmeyi benimseyen öğrenciler kendilerini diğerleri ile kıyaslarlar ve kendilerini yeniden motive ederek yetenek ve başarılarını kanıtlamaya yönelirken performans kaçınma yönelimine sahip öğrencilerin odağı diğer öğrencilere bağlı olarak bir öğrencinin yeteneğini veya yetenek eksikliğini göstermek isteksizliği olarak farklılaşmaktadır (Wolters, 2004). Öğrenme amaç ve performans amaçları üzerindeki genel yarg1 şudur: öğrenciler her ikisini de okulda alg1larlar ve edindikleri bu hedefleri benimserler ve bu da onların okuldaki davranışları üzerinde önemli faktörlerdir (Kaplan ve Maehr, 1999). Bu bakımdan öğrencilerin okullarda geçirdikleri yaşantı ve öğrenme deneyimlerinin oldukça önemli olduğu söylenebilir.

Başarı amaç yönelimi ile ilgili olarak literatür incelendiğinde içsel yada dişsal kaynaklara göre öğrenenlerin öğrenme sürecine katılma durumları da değişmektedir. Öğrenenler bazen derinlemesine öğrenmek için mücadele etmekte, bazen başarısız görünmemek için öğrenme sürecine katılmamaktadır. Bazen arkadaşlarının gözünde ben en iyiyim şeklinde algılanmak istemekte bazen de arkadaşlarının gözünde yine başarısız olmuş gibi görünmek şeklinde algılanmaktan dolayı yaklaşma ya da kaçınma davranışları sergilemektedirler. Örneğin, yaşadığımız toplumda öğrencinin hangi tür lisede öğrenim gördüğü önemlidir. Toplumun fen liselerinde öğrenim gören öğrenciler ile meslek liselerinde öğrenim gören öğrencilere bakış açıları farklı olabilmektedir. Aileler açısından çocuğunun fen lisesinde 
öğrenim görmesi tercih edilir bir durumdur. Bu nedenle öğrencinin öğrenim gördüğü lise türü, ailenin ortalama gelir düzeyi, cinsiyet farklılıkları ve ailede çocuk sayısı gibi değişkenler açısından lise öğrencilerinin başarı amaç yönelimlerinin (performans/öğrenme odaklı ya da kaçınma/yaklaşma davranışı) belirlenmesi bu liselerdeki öğrencileri tanıma ve davranışlarını anlamlandırmaya katkı sağlayacaktır. Bu araştırmada, öğrencilerin cinsiyetleri, öğrenim gördükleri lise türü, kendilerine ilişkin başarı algıları öğrencilerdeki başarı amaç yönelimleriyle anlamlı bir farklılık oluşturup oluşturmadığ1 tespit edilmesi amaçlanmaktadır. Buradan hareketle, araştırma sonucunda elde edilen verilerin öğrencileri tanıma, onları yönlendirme ve gerekse de motive etmede kullanılmak üzere öğretmenlere veri sağlayacağı düşünülmektedir.

\section{Yöntem}

$\mathrm{Bu}$ araştırma betimsel tarama türünde tasarlanmış nicel bir araştırmadır. Bu bölümde araştırmanın evren ve örneklem, ölçme araçları, verilerin toplanması ve analizine ilişkin bilgiler sunulmuştur.

\section{Evren ve Örneklem}

Araştırma evrenini Amasya ilinde liselerde öğrenim gören öğrenciler oluşturmaktadır. Türkiye İstatistik Kurumu (TÜİK) verilerine göre 2015-2016 öğretim yllinda Amasya ilinde bulunan lise sayıs1 63’tür. Bu okullarda 1062 şubede öğrenim gören öğrenci sayıları ise 12544 erkek ve 11905 kız olmak üzere toplam 24449'dur. Bu evrenden küme örnekleme yöntemiyle 15 lise örnekleme dâhil edilmiştir. Örnekleme giren okullardan her sınıf düzeyinde bir şube rasgele örnekleme yöntemiyle seçilmiş ve bu şubelerde ölçme araçlanı uygulanmıştır. Uygulama sonucunda 796 öğrenciden elde edilen veriler analize dâhil edilmiştir.

\section{Ölçme Araçları}

Araştırmada veriler araştırmacılar tarafından geliştirilen anket formu ve Türkçeye Arslan ve Akın (2015) tarafından uyarlanan 2x2 Başarı Amaç Yönelimi Ölçeği kullanılarak toplanmıştır. Toplam 26 maddeden oluşan ölçeğin öğrenme yaklaşma (8 madde), öğrenme kaçınma (5 madde), performans yaklaşma ( 7 madde) ve performans kaçınma ( 6 madde) olmak üzere 4 alt boyutu bulunmaktadır. Maddeler hiçbir zaman (1) ve her zaman (5) arasında değişen 5 sıklık derecesiyle yanıtlanmaktadır. Akın (2006) tarafindan 728 öğrenci üzerinde gerçekleştirilen uyarlama çalışması bulgularına göre ölçek dört boyutlu yapısıyla toplam puandaki değişimin \%67.25’ini açıklamaktadır. Cronbach alfa iç tutarlılık katsayıları sırasıyla 0.92 ile 0.97 arasında, test tekrar test güvenilirlik katsayıları ise 0.77 ile 0.86 arasında bulunmuştur. Bu çalışmada da Cronbach alfa iç tutarlılık katsayıları sırasıyla 0.73, 0.62, 0.75 ve 0.59 olarak hesaplanmıştır. Alt boyut puanları hesaplanırken toplam puan o alt boyutun içerdiği madde sayısına bölünmüştür. Bireyin hangi başarı yönelimini benimsediği ise en yüksek puanı aldığı alt boyut olarak belirlenmiştir.

\section{Verilerin Toplanmas1}

Veriler araştırmacılar tarafından örnekleme seçilen okullara gidilerek toplanmıstır. Okula gidildiği gün okul idaresinin iş birliği ile her sınıf düzeyinden bir şube seçilmiş, ölçme araçları ders saatleri içinde, sınıfta ve gözetim altında uygulanmıştır.

\section{Verilerin Analizi}

Veriler analiz edilmeden önce kullanılması düşünülen testlerin varsayımları kontrol edilmiştir. Normallik varsayımının incelenmesinde basıklık ve çarpıklık katsayılarının -1 ve +1 arasında yer alması kriterine bakılmış ayrıca histogram ve Q-Q grafikleri incelenmiştir. Bu incelemeler sonucunda puan dağılımlarının normallik varsayımın sağladığı görülmüştür. Bu nedenle iki ortalama arasındaki farkın karşılaştırılmasında ilişkisiz t testi, ikiden fazla grubun karşılaştırılmasında ise tek yönlü varyans analizi yöntemi kullanılmıştır. Varyans analizinde farklı bulunan grupların tespiti asgari önemli fark 
Kösterelioğlu, İ., Çelen, Ü., Akın Kösterelioğlu, M., \& Ahıska, A. R. (2019). Lise öğrencilerinin başarı amaç yönelimleri. Journal of Human Sciences, 16(2), 662-678, doi: 10.14687/ihs.v16i2.5603

(LSD) yöntemiyle yapılmıştır. Öğrencilerin başarı amaç yönelimi grubu ile diğer değişkenler arasındaki ilişki incelenirken ise ki-kare testinden yararlanılmıştır.

\section{Bulgular}

Anket formunun ve 2x2 Başarı Amaç Yönelimi Ölçeğinin uygulandığ1 796 öğrenciden elde edilen verilerin analizi ve ortaya çıkan sonuçlar aşağıda sunulmuştur.

Tablo 2. Öğrencilerin Cinsiyet, Sınıf Düzeyi ve Lise Türü Değişkenlerine Göre Dağılımı

\begin{tabular}{|c|c|c|c|c|c|}
\hline \multirow{2}{*}{ Cinsiyet } & \multirow{2}{*}{ Say1 } & \multirow{2}{*}{ Yüzde } & Lise Türü & Say1 & Yüzde \\
\hline & & & Anadolu Lisesi & 325 & 40.8 \\
\hline Erkek & 327 & 41.1 & Sosyal Bilimler Lisesi & 58 & 7.3 \\
\hline$K_{1 z}$ & 469 & 58.9 & Anadolu Sağllk Meslek Lisesi & 39 & 4.9 \\
\hline Toplam & 796 & 100.0 & Imam Hatip Lisesi & 64 & 8.0 \\
\hline Sinif & Say1 & Yüzde & Otelcilik ve Turizm Lisesi & 53 & 6.7 \\
\hline 1 & & & Teknik ve Endüstri Meslek Lisesi & 97 & 12.2 \\
\hline 2 & 226 & 28.4 & Ticaret Meslek Lisesi & 59 & 7.4 \\
\hline 3 & 176 & 22.1 & Kuz teknik ve Meslek Lisesi & 56 & 7.0 \\
\hline 4 & 163 & 20.5 & Fen Lisesi & 45 & 5.7 \\
\hline Toplam & 796 & 100.0 & Toplam & 796 & 100.0 \\
\hline
\end{tabular}

Tablo 2'de görüldüğü gibi araştırmaya katılan öğrencilerin \%41.1’i erkek, \%58.9’u k1z öğrencidir. \%29’u birinci sınıfta, \%20.5’i ise son sinıfta öğrenim görmektedir. Öğrencilerin yaklaşık yarısı (\%40.8) Anadolu lisesinde öğrenim görmektedir. Teknik ve endüstri meslek lisesinde öğrenip görüp araştırmaya katılmış olan öğrencilerin oranı \%12.2'dir. Bu oran diğer lise türlerinde $\% 4.9$ ile $\% 8.0$ arasindadir.

Tablo 3. Öğrencilerin 2x2 Başarı Amaç Yönelimi Ölçeğinden Aldıkları Puanların Tanımlayıcı İstatistikleri

\begin{tabular}{lcccc}
\hline İstatistik & $\begin{array}{c}\text { Öğrenme } \\
\text { Yaklaşma }\end{array}$ & $\begin{array}{c}\text { Öğrenme } \\
\text { Kaçınma }\end{array}$ & $\begin{array}{c}\text { Performans } \\
\text { Yaklaşma }\end{array}$ & $\begin{array}{c}\text { Performans } \\
\text { Kaçınma }\end{array}$ \\
\hline Ortalama & 3.77 & 3.23 & 3.12 & 2.81 \\
Medyan & 3.75 & 3.20 & 3.14 & 2.83 \\
Mod & 3.75 & 3.40 & 3.29 & 2.5 \\
Standart Sapma & 0.66 & 0.80 & 0.90 & 0.78 \\
\hline
\end{tabular}

Tablo 3’te öğrencilerin 2x2 Başarı Amaç Yönelimi Ölçeğinden aldıkları puanların tanımlayıcı istatistikleri sunulmuştur. Ortalamalar incelendiğinde öğrenme yaklaşma alt ölçeği puan ortalamasının en yüksek, performans kaçınma alt ölçeği puan ortalamasının ise en düşük olduğu görülmektedir.

Tablo 4. 2x2 Başarı Amaç Yönelimi Ölçeği Puanlarının Cinsiyete Göre Karşılaştırılması

\begin{tabular}{|c|c|c|c|c|c|c|c|c|c|}
\hline \multirow[b]{2}{*}{ Cinsiyet } & \multirow[b]{2}{*}{$\mathbf{n}$} & \multicolumn{2}{|c|}{$\begin{array}{l}\text { Ö̈ğrenme } \\
\text { Yaklaşma }\end{array}$} & \multicolumn{2}{|c|}{$\begin{array}{l}\text { Öğrenme } \\
\text { Kaçınma }\end{array}$} & \multicolumn{2}{|c|}{$\begin{array}{c}\text { Performans } \\
\text { Yaklaşma }\end{array}$} & \multicolumn{2}{|c|}{$\begin{array}{c}\text { Performans } \\
\text { Kaçınma }\end{array}$} \\
\hline & & $\bar{x}$ & $\mathbf{S}$ & $-\bar{x}$ & $\mathbf{S}$ & $-\bar{x}$ & $\mathbf{S}$ & $\bar{x}$ & $\mathbf{S}$ \\
\hline Erkek & 327 & 3.69 & 0.73 & 3.10 & 0.82 & 3.22 & 0.88 & 2.88 & 0.81 \\
\hline $\mathrm{K}_{12}$ & 469 & 3.83 & 0.60 & 3.32 & 0.78 & 3.04 & 0.90 & 2.76 & 0.75 \\
\hline Toplam & 796 & 3.77 & 0.66 & 3.23 & 0.80 & 3.12 & 0.90 & 2.81 & 0.78 \\
\hline$t, p$ & & \multicolumn{2}{|c|}{$\mathrm{t}=-2.96, \mathrm{p}=0.003$} & \multicolumn{2}{|c|}{$\mathrm{t}=-3.83, \mathrm{p}=0.000$} & \multicolumn{2}{|c|}{$\mathrm{t}=2.75, \mathrm{p}=0.006$} & \multicolumn{2}{|c|}{$\mathrm{t}=2.07, \mathrm{p}=0.039$} \\
\hline
\end{tabular}


Tablo 4'te erkek ve kız öğrencilerin 2x2 başarı amaç yönelimi alt ölçeklerinden aldıkları puan ortalamalarına ilişkin karşılaştırmalar sunulmuştur. Bütün alt ölçek puan ortalamaları arasında istatistiksel olarak anlamlı fark bulunmuştur $(\mathrm{p}<0.05)$. Öğrenme yaklaşma ve öğrenme kaçınma alt ölçeklerinde kızların, performans yaklaşma ve performans kaçınma alt ölçeklerinde ise erkeklerin puan ortalaması daha yüksektir.

Tablo 5. Cinsiyete Göre En Yüksek Puan Alınan Alt Ölçekler

\begin{tabular}{lcccccccc}
\hline & \multicolumn{2}{c}{$\begin{array}{c}\text { Öğrenme } \\
\text { Yaklaşma }\end{array}$} & \multicolumn{2}{c}{$\begin{array}{c}\text { Öğrenme } \\
\text { Kaçınma }\end{array}$} & \multicolumn{2}{c}{$\begin{array}{c}\text { Performans } \\
\text { Yaklaşma }\end{array}$} & \multicolumn{2}{c}{$\begin{array}{c}\text { Performans } \\
\text { Kaçınma }\end{array}$} \\
\cline { 2 - 10 } Cinsiyet & $\mathbf{n}$ & $\mathbf{0}$ & $\mathbf{n}$ & $\mathbf{\%}$ & $\mathbf{n}$ & $\mathbf{\%}$ & $\mathbf{n}$ & $\mathbf{\%}$ \\
\hline Erkek & 167 & 51.1 & 48 & 14.7 & 68 & 20.8 & 44 & 13.5 \\
K1z & 281 & 59.9 & 86 & 18.3 & 72 & 15.4 & 30 & 6.4 \\
\hline Toplam & $\mathbf{4 4 8}$ & $\mathbf{5 6 . 3}$ & $\mathbf{1 3 4}$ & $\mathbf{1 6 . 8}$ & $\mathbf{1 4 0}$ & $\mathbf{1 7 . 6}$ & $\mathbf{7 4}$ & $\mathbf{9 . 3}$ \\
\hline
\end{tabular}

$\chi^{2}=17.78, \mathrm{p}=0.000$

Öğrencilerin en yüksek puana sahip oldukları ölçek başarı amaç yönelimi türü olarak belirlenmiş bu dağılımın cinsiyete göre farklılık gösterip göstermediğine ilişkin olarak yapılan karşılaştırma Tablo 5’te sunulmuştur. Öğrencilerin yarıdan fazlasının (\%56.3) en yüksek puana sahip olduğu alt ölçek öğrenme yaklaşmadır. Bu öğrenme yaklaşımında yer alma yüzdesi kızlarda (\%59.9) erkeklerden (\%51.1) yüksektir. Benzer şekilde öğrenme kaçınma yaklaşımında yer alan kızların oranı (\%18.3), erkeklerden (\%14.7) fazladır. Performans yaklaşma ve performans kaçınma yaklaşımında ise durum tersine dönmüş ve bu yaklaşımlardaki erkek oranları kız oranlanından yüksek bulunmuştur. Yapılan karşılaştırmada başarı amaç yönelimi türlerinin dağılımının kız ve erkeklerde farklı olduğu bulunmuştur $\left(\chi^{2}=17.78, \mathrm{p}<0.05\right)$.

Tablo 6. 2x2 Başarı Amaç Yönelimi Ölçeği Puanlarının Sınıf Düzeyine Göre Karşılaştırılması

\begin{tabular}{lccccccccc}
\hline & & \multicolumn{2}{c}{$\begin{array}{c}\text { Öğrenme } \\
\text { Yaklaşma }\end{array}$} & \multicolumn{2}{c}{$\begin{array}{c}\text { Öğrenme } \\
\text { Kaçınma }\end{array}$} & \multicolumn{2}{c}{$\begin{array}{c}\text { Performans } \\
\text { Yaklaşma }\end{array}$} & \multicolumn{2}{c}{$\begin{array}{c}\text { Performans } \\
\text { Kaçınma }\end{array}$} \\
\cline { 2 - 11 } Sinıf & $\mathbf{n}$ & $-\bar{x}$ & $\mathbf{S}$ & $-\bar{x}$ & $\mathbf{S}$ & $-\bar{x}$ & $\mathbf{S}$ & $\bar{x}$ & $\mathbf{S}$ \\
\hline 1 & 231 & 3.82 & 0.68 & 3.27 & 0.83 & 3.24 & 0.91 & 2.86 & 0.80 \\
2 & 226 & 3.73 & 0.64 & 3.16 & 0.78 & 3.15 & 0.83 & 2.82 & 0.77 \\
3 & 176 & 3.77 & 0.66 & 3.26 & 0.74 & 3.15 & 0.89 & 2.91 & 0.77 \\
4 & 163 & 3.76 & 0.67 & 3.24 & 0.86 & 2.85 & 0.93 & 2.62 & 0.75 \\
\hline Toplam & $\mathbf{7 9 6}$ & $\mathbf{3 . 7 7}$ & $\mathbf{0 . 6 6}$ & $\mathbf{3 . 2 3}$ & $\mathbf{0 . 8 0}$ & $\mathbf{3 . 1 2}$ & $\mathbf{0 . 9 0}$ & $\mathbf{2 . 8 1}$ & $\mathbf{0 . 7 8}$ \\
\hline F, p & \multicolumn{3}{c}{$\mathrm{F}=0.77, \mathrm{p}=0.511$} & $\mathrm{~F}=0.83, \mathrm{p}=0.480$ & $\mathrm{~F}=6.56, \mathrm{p}=0.000$ & $\mathrm{~F}=4.59, \mathrm{p}=0.003$ \\
\hline
\end{tabular}

Öğrencilerin sınıf düzeylerine göre 2x2 başarı amaç yönelimi puan ortalamaları Tablo 6'da sunulmuştur. Öğrenme yaklaşma ve öğrenme kaçınma alt ölçeklerinden alınan puan ortalamalarının sınıf düzeyine göre farklılık göstermediği görülmüştür ( $p>0.05$ ). Performans yaklaşma ve kaçınma alt ölçeklerinde ise sınıf düzeyine göre istatistiksel olarak anlamlı bir farkll1ık söz konusudur $(\mathrm{p}<0.05)$. Yapılan ikili karşılaştırmalarda her iki alt ölçekte de 4. sınıf öğrencilerinin puan ortalamalarının diğer sinıflarda öğrenim gören öğrencilerden düşük olduğu bulunmuştur. 
Kösterelioğlu, İ., Çelen, Ü., Akın Kösterelioğlu, M., \& Ahıska, A. R. (2019). Lise öğrencilerinin başarı amaç yönelimleri. Journal of Human Sciences, 16(2), 662-678, doi: 10.14687/ihs.v16i2.5603

Tablo 7. Sınıf Düzeyine Göre En Yüksek Puan Alınan Alt Ölçekler

\begin{tabular}{lcccccccc}
\hline & \multicolumn{2}{c}{$\begin{array}{c}\text { Öğrenme } \\
\text { Yaklaşma }\end{array}$} & \multicolumn{2}{c}{$\begin{array}{c}\text { Öğrenme } \\
\text { Kaçınma }\end{array}$} & \multicolumn{2}{c}{$\begin{array}{c}\text { Performans } \\
\text { Yaklaşma }\end{array}$} & \multicolumn{2}{c}{$\begin{array}{c}\text { Performans } \\
\text { Kaçınma }\end{array}$} \\
\cline { 2 - 9 } Sınıf & $\mathbf{n}$ & $\mathbf{0}$ & $\mathbf{n}$ & $\mathbf{\%}$ & $\mathbf{n}$ & $\mathbf{\%}$ & $\mathbf{n}$ & $\mathbf{\%}$ \\
\hline 1 & 126 & 54.5 & 42 & 18.2 & 43 & 18.6 & 20 & 8.7 \\
2 & 133 & 58.8 & 31 & 13.7 & 35 & 15.5 & 27 & 11.9 \\
3 & 97 & 55.1 & 26 & 14.8 & 35 & 19.9 & 18 & 10.2 \\
4 & 92 & 56.4 & 35 & 21.5 & 27 & 16.6 & 9 & 5.5 \\
\hline Toplam & $\mathbf{4 4 8}$ & $\mathbf{5 6 . 3}$ & $\mathbf{1 3 4}$ & $\mathbf{1 6 . 8}$ & $\mathbf{1 4 0}$ & $\mathbf{1 7 . 6}$ & $\mathbf{7 4}$ & $\mathbf{9 . 3}$ \\
\hline
\end{tabular}

$\chi^{2}=10.32, p=0.325$

Tablo 7'de öğrencilerin en yüksek puana sahip oldukları ölçek başarı amaç yönelimi türünün sınıf düzeyine göre farklılık gösterip göstermediğine ilişkin olarak yapılan karşılaştırma sunulmuştur. Yapılan karşılaşıırmada başarı amaç yönelimi türlerinin dağılımının sınıf düzeyine göre farklı olmadığ1 görülmektedir $\left(\chi^{2}=10.32, \mathrm{p}>0.05\right)$.

Tablo 8. 2x2 Başarı Amaç Yönelimi Ölçeği Puanlarının Lise Türüne Göre Karşılaştırılması

\begin{tabular}{lccccccccc} 
& & \multicolumn{2}{c}{$\begin{array}{c}\text { Ögrenme } \\
\text { Yaklaşma }\end{array}$} & \multicolumn{2}{c}{$\begin{array}{c}\text { Öğrenme } \\
\text { Kaçınma }\end{array}$} & \multicolumn{2}{c}{$\begin{array}{c}\text { Performans } \\
\text { Yaklaşma }\end{array}$} & \multicolumn{2}{c}{$\begin{array}{c}\text { Performans } \\
\text { Kaçınma }\end{array}$} \\
\cline { 2 - 11 } Lise Türü & $\mathbf{n}$ & $-\bar{x}$ & $\mathbf{S}$ & $\bar{x}$ & $\mathbf{S}$ & $-\bar{x}$ & $\mathbf{S}$ & $\bar{x}$ & $\mathbf{S}$ \\
\hline Anadolu, Fen, Sosyal Bilimler L. & 428 & 3.70 & 0.65 & 3.20 & 0.81 & 2.86 & 0.86 & 2.71 & 0.75 \\
İmam Hatip Lisesi & 64 & 3.86 & 0.65 & 3.13 & 0.82 & 3.44 & 0.90 & 2.73 & 0.81 \\
Meslek Liseleri & 304 & 3.86 & 0.67 & 3.31 & 0.78 & 3.40 & 0.84 & 2.97 & 0.80 \\
\hline Toplam & $\mathbf{7 9 6}$ & $\mathbf{3 . 7 7}$ & $\mathbf{0 . 6 6}$ & $\mathbf{3 . 2 3}$ & $\mathbf{0 . 8 0}$ & $\mathbf{3 . 1 2}$ & $\mathbf{0 . 9 0}$ & $\mathbf{2 . 8 1}$ & $\mathbf{0 . 7 8}$ \\
\hline F, p & \multicolumn{4}{c}{$\mathrm{F}=5.97}$, & $\mathrm{F}=2.30$, & $\mathrm{F}=40.61$, & $\mathrm{F}=9.86$, \\
& & $\mathrm{p}=0.003$ & $\mathrm{p}=0.101$ & $\mathrm{p}=0.000$ & $\mathrm{p}=0.000$ \\
\hline
\end{tabular}

Öğrencilerin 2x2 başarı amaç yönelimi ölçeğinden almış oldukları puanların lise türüne göre karşılaştırılmasına ilişkin bulgular Tablo 8 'de verilmiştir. Tablo 8 incelendiğinde öğrenme kaçınma alt ölçeği puan ortalamalarının lise türüne göre farklılık göstermediği görülmektedir ( $\mathrm{p}>0.05)$. Diğer alt ölçek puan ortalamaları ise lise türüne göre istatistiksel olarak anlamlı şekilde farklıdır $(p<0.05)$. Öğrenme yaklaşma ve performans yaklaşma alt ölçeklerinde imam hatip ve meslek lisesinde öğrenim gören öğrencilerin puan ortalamaları Anadolu, fen ve sosyal bilimler liselerinde öğrenim gören öğrencilerden yüksektir. Performans kaçınma alt ölçeğinde ise meslek lisesi öğrencilerinin puan ortalamaları diğer liselerdeki öğrencilerin puan ortalamalarından yüksektir.

Tablo 9. Lise Türüne Göre En Yüksek Puan Alınan Alt Ölçekler

\begin{tabular}{lcccccccc}
\hline & $\begin{array}{c}\text { Öğrenme } \\
\text { Yaklaşma }\end{array}$ & \multicolumn{2}{c}{$\begin{array}{c}\text { Öğrenme } \\
\text { Kaçınma }\end{array}$} & \multicolumn{2}{c}{$\begin{array}{c}\text { Performans } \\
\text { Yaklaşma }\end{array}$} & \multicolumn{2}{c}{$\begin{array}{c}\text { Performans } \\
\text { Kaçınma }\end{array}$} \\
\cline { 2 - 10 } Lise Türü & $\mathbf{n}$ & $\mathbf{0}$ & $\mathbf{n}$ & $\mathbf{0}$ & $\mathbf{n}$ & $\mathbf{\%}$ & $\mathbf{n}$ & $\mathbf{\%}$ \\
\hline Anadolu, Fen, Sosyal Bilimler L. & 250 & 58.4 & 80 & 18.7 & 53 & 12.4 & 45 & 10.5 \\
İmam Hatip Lisesi & 34 & 53.1 & 8 & 12.5 & 20 & 31.2 & 2 & 3.1 \\
Meslek Liseleri & 164 & 53.9 & 46 & 15.1 & 67 & 22.0 & 27 & 8.9 \\
\hline Toplam & $\mathbf{4 4 8}$ & $\mathbf{5 6 . 3}$ & $\mathbf{1 3 4}$ & $\mathbf{1 6 . 8}$ & $\mathbf{1 4 0}$ & $\mathbf{1 7 . 6}$ & $\mathbf{7 4}$ & $\mathbf{9 . 3}$ \\
\hline
\end{tabular}

$\chi^{2}=23.04, \mathrm{p}=0.001$

Tablo 9'da en yüksek alınan alt ölçeğin lise türlerine göre dağılımı sunulmuştur. Yapılan ki-kare testi sonuçlarına göre benimsenen öğrenme yaklaşımı ile lise türü arasında anlamlı bir ilişki vardır ( $\mathrm{p}<0.05)$. Öğrenme yaklaşma ve öğrenme kaçınma yönelimini benimseyen öğrenci oranı Anadolu fen ve sosyal bilimler liselerinde öğrenim gören öğrencilerde diğer öğrencilerden yüksektir. En belirgin 
Kösterelioğlu, İ., Çelen, Ü., Akın Kösterelioğlu, M., \& Ahıska, A. R. (2019). Lise öğrencilerinin başarı amaç yönelimleri. Journal of Human Sciences, 16(2), 662-678, doi: 10.14687/ihs.v16i2.5603

farklılık performans yaklaşma alt ölçeğinde göze çarpmaktadır. Bu yönelimi benimseyen öğrenci oranı imam hatip lisesindeki ögrencilerde \%31.2, meslek liselerinde \%22.0 ve Anadolu, fen ve sosyal bilimler liselerinde \%12.4'tür.

Tablo 10. 2x2 Başarı Amaç Yönelimi Ölçeği Puanlarının Öğrencilerin Başarı Algılarına Göre Karşılaştırılması

\begin{tabular}{|c|c|c|c|c|c|c|c|c|c|}
\hline \multirow[b]{2}{*}{ Başarı Algısı } & \multirow[b]{2}{*}{$\mathbf{n}$} & \multicolumn{2}{|c|}{$\begin{array}{l}\text { Öğrenme } \\
\text { Yaklaşma }\end{array}$} & \multicolumn{2}{|c|}{$\begin{array}{l}\text { Öğrenme } \\
\text { Kaçınma }\end{array}$} & \multicolumn{2}{|c|}{$\begin{array}{c}\text { Performans } \\
\text { Yaklaşma }\end{array}$} & \multicolumn{2}{|c|}{$\begin{array}{c}\text { Performans } \\
\text { Kaçınma }\end{array}$} \\
\hline & & $\bar{x}$ & $\mathbf{S}$ & $\bar{x}$ & $\mathbf{S}$ & $\bar{x}$ & $\mathbf{S}$ & $\bar{x}$ & $\mathbf{S}$ \\
\hline Başarısız & 29 & 3.19 & 0.80 & 2.99 & 1.02 & 2.95 & 0.95 & 2.67 & 0.80 \\
\hline Kismen & 93 & 3.43 & 0.63 & 3.12 & 0.82 & 2.99 & 0.89 & 2.96 & 0.78 \\
\hline \multicolumn{10}{|l|}{ Başarısız } \\
\hline Kısmen Başarilı & 447 & 3.76 & 0.60 & 3.23 & 0.76 & 3.08 & 0.87 & 2.80 & 0.79 \\
\hline Başarılı & 227 & 4.02 & 0.66 & 3.32 & 0.82 & 3.25 & 0.92 & 2.79 & 0.74 \\
\hline Toplam & 796 & 3.77 & 0.66 & 3.23 & 0.80 & 3.12 & 0.90 & 2.81 & 0.78 \\
\hline$F, p$ & & \multicolumn{2}{|c|}{$\begin{array}{l}F=28.85, \\
p=0.000\end{array}$} & \multicolumn{2}{|c|}{$\begin{array}{l}\mathrm{F}=2.50, \\
\mathrm{p}=0.058\end{array}$} & \multicolumn{2}{|c|}{$\begin{array}{l}\mathrm{F}=2.75, \\
\mathrm{p}=0.042\end{array}$} & \multicolumn{2}{|c|}{$\begin{array}{l}F=1.56, \\
p=0.198\end{array}$} \\
\hline
\end{tabular}

Öğrencilerin başarı amaç yönelimi alt ölçeğinden aldıkları puanların başarı algılarına göre karşılaştırılmasına ilişkin bulgular Tablo 10'da verilmiştir. Öğrenme yaklaşma ve performans kaçınma alt ölçeği puan ortalamaları öğrencilerin başarı algılarına göre anlamlı bir farklılık göstermemektedir ( $>$ >0.05). Öğrenme yaklaşma ve performans yaklaşma alt ölçekleri puan ortalamaları ise başarı algısına göre istatistiksel olarak anlamlı şekilde farklılaşmaktadır $(\mathrm{p}<0.05)$. Öğrenme yaklaşma alt ölçeğinde başarılı olduğunu düşünen öğrencilerin puan ortalaması diğer başarı alg1sı durumlarından, kısmen başarılı olduğunu düşünenlerinki ise kısmen başarısız ve başarısız olanlardan yüksektir. Performans yaklaşma alt ölçeğinde ise başarllı olduğunu düşünen öğrencilerin puan ortalamaları diğerlerinden yüksektir.

Tablo 11. Öğrencinin Başarı Algısına Göre En Yüksek Puan Alınan Alt Ölçekler

\begin{tabular}{|c|c|c|c|c|c|c|c|c|}
\hline \multirow[b]{2}{*}{ Başarı Algısı } & \multicolumn{2}{|c|}{$\begin{array}{l}\text { Öğrenme } \\
\text { Yaklaşma }\end{array}$} & \multicolumn{2}{|c|}{$\begin{array}{l}\text { Öğrenme } \\
\text { Kaçınma }\end{array}$} & \multicolumn{2}{|c|}{$\begin{array}{c}\text { Performans } \\
\text { Yaklaşma }\end{array}$} & \multicolumn{2}{|c|}{$\begin{array}{c}\text { Performans } \\
\text { Kaçınma }\end{array}$} \\
\hline & $\mathrm{n}$ & $\%$ & $\mathbf{n}$ & $\%$ & $\mathbf{n}$ & $\%$ & $\mathrm{n}$ & $\%$ \\
\hline Başarısız & 12 & 41.4 & 3 & 10.3 & 10 & 34.5 & 4 & 13.8 \\
\hline Kısmen Başarısız & 35 & 37.6 & 24 & 25.8 & 16 & 17.2 & 18 & 19.4 \\
\hline Kısmen Başarıll & 252 & 56.4 & 75 & 16.8 & 75 & 16.8 & 45 & 10.1 \\
\hline Başarılı & 149 & 65.6 & 32 & 14.1 & 39 & 17.2 & 7 & 3.1 \\
\hline Toplam & 448 & 56.3 & 134 & 16.8 & 140 & 17.6 & 74 & 9.3 \\
\hline
\end{tabular}

Tablo 11 incelendiğinde öğrencilerin başarı algılarıla en yüksek puan aldıkları başarı amaç yönelimi alt ölçeği arasında istatistiksel olarak anlamlı bir ilişki olduğu görülmektedir. Kendini kısmen başarılı ve başarıll gören öğrencilerin öğrenme yaklaşma yönelimini benimseme yüzdesi kısmen başarısız ve başarısız görenlerden fazladır. Kısmen başarısız öğrencilerde öğrenme kaçınma ve performans kaçınma yönelimini benimseme yüzdesi, başarısız gören öğrencilerde ise performans yaklaşma yönelimini benimseyen öğrenci yüzdesi diğerlerinden fazladır.

\section{Tartışma}

Araştırma bulgulan değerlendirildiğinde, tüm ölçek alt puan ortalamaları arasında istatistiksel olarak öğrenme amaç yönelimi alt ölçeklerinde kızların, performans amaç yönelimi alt ölçeklerinde ise erkeklerin lehine anlamlı sonuç elde edilmiştir. Smith ve Sinclair (2005) ise araştırmalarında 

Journal of Human Sciences, 16(2), 662-678, doi: 10.14687/jhs.v16i2.5603

katılımcıların cinsiyetleri ile başarı amaç yönelimleri arasında anlamlı bir ilişki tespit etmemiştir. Diğer taraftan, Ablard ve Lipschultz (1998) kızların öğrenmeye Freudenthaler, Spinath ve Neubaue (2008) ise erkeklerin performansa önem verdiklerini tespit etmişlerdir. Hanrahan ve Cerin'de (2009) kızların öğrenme-yaklaşma yöneliminde oldukları bulgusunu elde etmiştir. Barron, Finney, Davis ve Owens (2003) araştırmalarında yüksek yeterlik beklentisi ile akademik başarınının öğrenme ve performans yaklaşma yönelimlerini yordadığını tespit etmiş, söz konusu beklenti ve akademik başarının düşük olmasının da performans-kaçınma yönelimleri ile ilişkili olduğunu bulmuştur. Araştırmada ayrıca, performans-yaklaşma amaçlarının olumlu akademik sonuçlarka olumlu yönde ilişkili olduğu tespit edilmiştir. İzci ve Koç (2012) araştırmalarında pedagojik formasyon eğitimi alan öğrenciler üzerinde yürüttüğü araştırmada, katıllımcıların cinsiyetlerinin öğrenme yönelimi, performans-yaklaşma, performans-kaçınmaya göre anlamlı düzeyde farklılık olmadığı bulgusunu elde etmiştir. Küçükoğlu, Kaya ve Turan (2010) araştırmalarında öğrenme yönelimi ve performans-yaklaşma yöneliminin öğrencilerin başarı düzeylerinde yüksek düzeyde etkiye sahip olduğunu, performans-kaçınma yönelimlerinin ise öğrenci başarıları üzerinde daha az bir etki düzeyine sahip olduğu bulgusunu elde etmiştir. Pekrun, Elliot ve Maier'de (2006) araştırmalarında amaç yönelimlerinin performans amaçları üzerinde etkili olduğu bulgusunu elde etmiştir. Régner, Loose ve Dumas (2009) aileler ve öğretmenler tarafından sağlanan akademik izleme algılarının öğrencileri performans amaç yönelimlerine yönlendirdiği bulgusunu elde etmiştir. Rosas (2015) araştırmasında performans-yaklaşmanın akademik performans üzerinde pozitif bir yordayıc1 olduğu bulgusunu elde etmiştir. Soltaninejad (2015) araştırmasında öğrenme-yaklaşma, öğrenme-kaçınma amaç yönelimlerinin performansyaklaşma, performans-kaçınma amaç yönelimleri ile negatif yönde ilişkili olduğu bulgusunu elde etmiştir.

Araştırmada öğrencilerin en yüksek puana sahip oldukları yönelim, öğrenme amaç yönelimi olduğu tespit edilmiştir. Öğrencilerin yarıdan fazlasının en yüksek puana sahip olduğu alt ölçek ise öğrenme yaklaşmadır. Bu öğrenme yaklaşımında yer alma yüzdesi kızlarda erkeklerden yüksektir. Benzer şekilde öğrenme kaçınma yaklaşımında yer alan kızların oranı erkeklerden fazladır. Performans yaklaşma ve performans kaçınma yaklaşımında ise durum tersine dönmüş ve bu yaklaşımlardaki erkek oranları kız oranlarından yüksek bulunmuştur. Küçükoğlu, Kaya ve Turan (2010) araştırmalarında katılımcıların öğrenme yönelimi ortalamaları değerlendirildiğinde kız öğrenciler lehine anlamlı düzeyde bir farklılık olduğunu tespit etmişlerdir. Katılımcıların cinsiyet değişkenine göre performansyaklaşma yönelimlerine ilişkin ortalamaların kız öğrenciler lehine anlamlı düzeyde farklılaştığını, performans-kaçınma yönelimlerine ilişkin ortalamalarda ise farklılaşmadığını tespit edilmiştir (Küçükoğlu, Kaya ve Turan, 2010). Buldur (2014) ise araştırmasında öğrencilerin sınıf-içi değerlendirme ortamına dair algıları ile başarı amaç yönelimleri arasında anlamlı bir ilişki olduğunu, ancak katılımcıların cinsiyetlerinin benimsenen başarı amaç yönelimi üzerinde etkili olmadığını tespit etmiştir. Dinç (2010) ve Aydın (2014)'ın öğretmen adayları üzerinde yürüttüğü araştırmada öğretmen adayları en çok öğrenme yönelimine sahip maddelere yönelim göstermişlerdir. Arslan'da (2011) araştırmasında aday öğretmenlerin öğrenme yönelimlerinin performans yönelimlerine göre daha yüksek olduğunu tespit etmiş ve öğretmen adaylarının olumsuz eleştirilerden uzak durmak ve kendilerini kanıtlamaktan ziyade, ihtiyaç duydukları bilgi ve becerileri edinmek amaciyla derse katıldıklarını tespit etmiştir.

Araştırmada, öğrenme yaklaşma ve öğrenme kaçınma alt ölçeklerinden alınan puan ortalamalarının sınıf düzeyine göre farklılık göstermediği görülmüştür. Buradan hareketle, öğrenmeye ilişkin öğrenende oluşan motivasyon öğrenme odaklı olduğundan dolayı hangi sınıf seviyesinde olursa olsun motivasyonlarının olumsuz etkilenmediği söylenebilir. Bu kapsamda Rawsthorne ve Elliot'un (1999) 1971-1997 yılları arasında başarı hedefleri ve içsel motivasyon konusunda yayınlanan makaleler üzerinde yaptıkları meta analiz sonuçlarına göre de öğrenme hedeflerinin, performans hedeflerine göre içsel motivasyon üzerinde daha etkili olduğu tespit edilmiştir. Harackiewicz, Durik, Barron, Linnenbrink-Garcia, ve Tauer (2008) araştırmalarında, öğrenme amaç yönelimlerinin öğrencilerin ilgisini arttırdığını ve motivasyon kaynağı olduğunu tespit etmiştir. Akın (2008) ise araştırmasında öz- 
duyarlık ve başarı yönelimi arasındaki ilişkiyi incelemiş ve öz-duyarllğın öz-sevecenlik, paylaşımların bilincinde olma ve bilinçlilik alt boyutlarının öğrenme-yaklaşma ve öğrenme-kaçınma yönelimleriyle pozitif, performans-yaklaşma ve performans-kaçınma yönelimleriyle negatif ilişkili olduğunu tespit etmiştir. Diğer taraftan, öz-duyarlık ile ilgili diğer alt boyutlarda öz-yargilama, izolasyon ve aşırı özdeşleşme ise öğrenme-yaklaşma ile negatif, öğrenme-kaçınma, performans-yaklaşma ve performans-kaçınma yönelimleriyle pozitif ilişkili bulunmuştur. Bartels ve Magun-Jackson (2009) araştırmalarında öz düzenleme ve amaç yönelimi arasındaki ilişkiyi incelemiş ve katılımcıların başarıya duydukları ihtiyaç ile öz-düzenleme arasında anlamlı bir ilişki tespit etmiştir. Araştırma sonucunda, başarısız olma kaygısı ve öz-düzenleme becerisi arasında negatif yönlü bir ilişki tespit edilirken, amaç yönelimlerinin bu ilişkiyi etkilemediği bulunmuştur (Bartels ve Magun-Jackson, 2009). Kadıoğlu ve Kondakçı (2014) lise öğrencilerinin kimya dersine ilişkin benimsedikleri öğrenme stratejileri ile sahip oldukları hedef yönelimlerini incelediği araştırmasında, öğrenme-yaklaşma hedefleri ile bilişüstü özdüzenleme stratejileri arasından anlamlı düzeyde ilişki tespit etmiş ve yeni beceriler kazanmak isteyen öğrencilerin yüksek düzeyde farkındalıkla ders çalışırken plan yapma stratejilerinden yararlandığ1 bulgusunu elde etmiştir. Hulleman, Durik, Schweigert ve Harackiewicz (2008) araştırmalarında öğrenme-yaklaşma amaçları ve derse ilişkin ön ilginin motivasyonuyordadığını tespit etmiş ve performans-yaklaşma amaçlarının öğrenmeye karşı olumlu tutumu açıkladığı bulgusuna erişmişlerdir. Isoard-Gautheur, Guillet-Descas ve Duda'da (2013) araştırmalarında sezon başında öğrenme-yaklaşma amaçları yüksek olan sporcuların sezon sona erdiğinde daha düşük seviyede tükenmişlik yaşadıklarını bulmuştur. Küçükoğlu, Kaya ve Turan (2010) araştırmalarında sınıf öğretmeni adaylarının öğrenme yönelimlerini incelemiş ve 1. sınıfta öğrenim gören öğrenciler lehine anlamlı düzeyde bir farklılaşma; katılımcıların performans-yaklaşma yönelimlerine ilişkin 1. sınıfta öğrenim gören öğrencileri lehine anlamlı bir farklılık olduğunu, performans-kaçınma yönelimi ortalamalarında ise sınıf değişkenine göre farklılık olmadığını tespit etmiştir.

Öğrenim görülen lise türü açısından ele alındığında, öğrenme kaçınma alt ölçeği puan ortalamalarının lise türü değişkeni açısından farklılık göstermediği bulunmuştur. Diğer alt ölçek boyutlarında ise istatistiksel açıdan anlamlı farklılık tespit edilmiştir. Bu doğrultuda, öğrenme yaklaşma ve performans yaklaşma alt ölçeklerinde imam hatip ve meslek lisesinde öğrenim gören öğrencilerin puan ortalamaları Anadolu, fen ve sosyal bilimler liselerinde öğrenim gören öğrencilerden yüksektir. Performans kaçınma alt ölçeğinde ise meslek lisesi öğrencilerinin puan ortalamaları diğer liselerdeki öğrencilerin puan ortalamalarından yüksektir. Analiz sonuçlarına göre benimsenen öğrenme yaklaşımı ile lise türü arasında anlamlı bir ilişki bulunmaktadır. Öğrenme yaklaşma ve öğrenme kaçınma yönelimini benimseyen öğrenci oranı Anadolu, fen ve sosyal bilimler liselerinde öğrenim gören öğrencilerde diğer öğrencilerden yüksektir. En belirgin farkllık performans yaklaşma alt ölçeğinde göze çarpmaktadır. İzci ve Koç (2012) araştırmalarında katıllmcıların mezun olduğu lise türünün başarı yönelimlerinin alt boyutları, öğrenme yönelimi, performans-yaklaşma, performans kaçınmaya göre anlamlı farklılık göstermediği sonucuna ulaşmıştır.

Araştırmada ayrıca öğrenme yaklaşma ve performans kaçınma alt ölçeği puan ortalamaları öğrencilerin başarı algılarına göre anlamlı bir farklılık göstermediği tespit edilmiştir. Öğrenme yaklaşma ve performans yaklaşma alt ölçekleri puan ortalamaları ise başarı algısına göre istatistiksel olarak anlamlı şekilde farklılaşmaktadır. Öğrenme yaklaşma alt ölçeğinde başarılı olduğunu düşünen öğrencilerin puan ortalaması diğer başarı alg1sı durumlarından, kısmen başarılı olduğunu düşünenlerinki ise kısmen başarısız ve başarısız olanlardan yüksektir. Performans yaklaşma alt ölçeğinde ise başarllı olduğunu düşünen öğrencilerin puan ortalamaları diğerlerinden yüksektir. İzci ve Koç (2012) araştırmalarında pedagojik formasyon öğrencilerinin akademik başarıya ilişkin algılarının öğrenme yönelimine göre anlamlı farklılık göstermediğini, ancak performans-yaklaşma, performans-kaçınmaya göre anlamlı düzeyde farklılaştığını ve bu farklılı̆̆ın da akademik başarı algıları "orta düzeyde başarılı" olanların lehinde olduğunu tespit etmiştir. 
Wang, Liu, Lochbaum ve Stevenson (2009), 309 üniversite öğrencisi ile yaptıkları çalışmada, öğrencileri fiziksel aktiviteler konusunda kendi yetenek algilarına göre üst düzey yetenek grubu ve düşük düzey yetenek grubu olmak üzere iki gruba ayırmışlardır. Her bir grup için hedef yönelimlerinin içsel motivasyonu nasıl etkilediğini test etmişlerdir. Araştırma sonuçları her iki grupta da sadece öğrenme yaklaşma hedeflerinin içsel motivasyonu pozitif yönde ve anlamlı olarak etkilediği, öğrenme kaçınma hedeflerinin ise yalnızca düşük düzey yetenek grubu için içsel motivasyonu anlamlı fakat negatif yönde etkilediği bulunmuştur. Diğer yandan performans kaçınma ve performans yaklaşma hedefleri her iki grupta da içsel motivasyonla ilişkili bulunmamıştır.

Araştırma bulgularına göre, öğrencilerin başarı algılarıyla en yüksek puan aldıkları başarı amaç yönelimi alt ölçeği arasında istatistiksel olarak anlamlı bir ilişki olduğu görülmektedir. Kendini kısmen başarılı ve başarılı gören öğrencilerin öğrenme yaklaşma yönelimini benimseme yüzdesi kısmen başarısız ve başarısız görenlerden fazladır. Kısmen başarısız öğrencilerde öğrenme kaçınma ve performans kaçınma yönelimini benimseme yüzdesi, başarısız gören öğrencilerde ise performans yaklaşma yönelimini benimseyen öğrenci yüzdesi diğerlerinden fazladır. Ames ve Archer (1988) yaptıkları araştırmada, sınıf içerisinde amaç yönelimli öğrencilerin etkili stratejiler kullandıklarını, zorlayıcı çalş̧maları tercih ettiklerini ve başarının çaba sonucu ortaya çıkan bir durum olduğunu düşündüklerini tespit etmiştir. Akın ve Arslan (2014) başarı amaç yönelimleri ile kararlllık arasındaki ilişkiyi incelemiş ve araşturma sonucunda, öğrenme-yaklaşma amaç yönelimini kararlllık ile pozitif yönde ilişkili olduğunu tespit etmiştir. Diğer taraftan, öğrenme-kaçınma amaç yönelimi, peformans / yaklaşma/kaçınma amaç yönelimlerinin kararlılık ile negatif yönde ilişkili olduğu bulunmuştur. Araştırma bulgularına göre, başarı amaç yönelimleri kararlılığın önemli bir belirleyicisi olduğu ve başarı ve motivasyon ile doğrudan ilişkili olduğu belirtilmiştir. Akpur (2016), üniversite öğrencilerinin amaç yönelim davranışları ile akademik başarılarını incelediği araştırmasında, öğrenme-yaklaşma, öğrenmekaçınma ve performans yaklaşmanın akademik başarının önemli yordayıcıları olmadığını, Antoniou (2014) ise öğrenme-yaklaşma ve öğrenme-kaçınmanın akademik başarının olumlu yönde yordayıcıları olduğu bulgusunu elde etmiştir.

\section{Sonuç ve Öneriler}

Araştırmadan elde edilen sonuçlar şu şekilde özetlenebilir.

- Ortalamalar incelendiğinde öğrenme yaklaşma alt ölçeği puan ortalamasının en yüksek, performans kaçınma alt ölçeği puan ortalaması ise en düşüktür.

- Öğrenme yaklaşma ve öğrenme kaçınma alt ölçeklerinde kızların, performans yaklaşma ve performans kaçınma alt ölçeklerinde ise erkeklerin puan ortalaması daha yüksektir.

- Öğrencilerin sınıf düzeyleri başarı amaç yönelimi puan ortalamaları sınıf düzeyine göre farklilık göstermemektedir.

- Öğrencilerin lise türüne göre puanları incelendiğinde öğrenme kaçınma alt ölçeği puan ortalamalarının lise türüne göre farklılık göstermediği diğer alt ölçek puan ortalamalarında ise istatistiksel olarak anlamlı şekilde farkllık bulunmamaktadır.

- Öğrencilerin başarı algılarıyla en yüksek puan aldıkları başarı amaç yönelimi alt ölçeği arasında istatistiksel olarak anlamlı bir ilişki tespit edilmiştir. Kendini kısmen başarılı ve başarılı gören öğrencilerin öğrenme yaklaşma yönelimini benimseme yüzdesi kısmen başarısız ve başarısız görenlerden fazladır.

Araştırmadan elde edilen sonuçlara bağlı olarak şu öneriler geliştirilmiştir.

- Okullarda rehberlik servislerinin öğrencilere düzenleyeceği başarı amaç yönelimi anketleri aracılığıyla öğrencilerin başarı yönelimleri ortaya konulabilir.

- Elde edilen sonuçlar öğretmenlerle paylaşılarak öğrencilerin daha iyi tanınması sağlanabilir.

- Öğrencilerin başarı yönelimlerinin dikkate alınacağı öğrenme grupları oluşturarak öğrenme çıtuları değerlendirilebilir. 
Kösterelioğlu, İ., Çelen, Ü., Akın Kösterelioğlu, M., \& Ahıska, A. R. (2019). Lise öğrencilerinin başarı amaç yönelimleri. Journal of Human Sciences, 16(2), 662-678, doi: 10.14687/ihs.v16i2.5603

- Öğrencileri öğrenme yaklaşma odaklı olacak biçimde öğrenmeye yönlendirmek ve motivasyonu sürdürmeye yönelik uygulamalara yer verilebilir.

- İleriki süreçlerde yapılacak farklı araştırmalarda, öğrencilerin başarı yönelimlerini etkileyen etmenler üzerine öğrencilerle görüşmeler yapılarak araştırma derinleştirilebilir.

\section{Kaynakça}

Ablard, K. E. ve Lipschultz, R. E. (1998). Self regulated learning in high-achieving students: Relations to advanced reasoning, achievement goals, and gender. Journal of Educational Psychology, 90, 94- 101.

Agbuga, B. ve Xiang, P. (2008). Achievement Goalsand Their Relationsto Self-Reported Persistence/Effort in Secondary Physical Education: A Trichotomous Achievement Goal Framework. Journal of Teaching in Physical Education, 27, 179-191.

Ağbuğa, B. (2014). 3 x 2 Başarı Hedef Modeli Ölçeğinin Türk Lisans Öğrencileri İçin Geçerlik ve Güvenirlik Çalışması. Hacettepe Journal of Sport Sciences, 25(3), 109-117

Akın, A. (2006). 2X2 Başarı Yönelimleri Ölçeği: Geçerlik ve güvenirlik çalısması. Sakarya Üniversitesi Ë̆gitim Fakültesi Dergisi, 12, 1-13.

Akın, A. (2008). Self-compassion and Achievement Goals: A Structural Equation ModelingApproach. Eurasian Journal of Educational Research, 31,1-15.

Akın, A. ve Arslan, S. (2014). The relationships between achievement goal orientations and grit. Egitim ve Bilim, 39(175), 267-274

Akpur, U. (2016). The explanatory and predictive relationship pattern between university students' goal orientation behaviours and their academic achievement. Educational Research and Reviews, 11(17), $1650-1658$.

Albaili. M. A. (1998). Goal orientations. Cognitive strategies and academic achievement of United Arab Emirates college students. Educational Psychology, 18(2), 195-203.

Ames, C. ve Archer, J. (1988). Achievement goals in the classroom: Students' learning strategies and motivation processes. Journal of Educational Psychology, 80, 260-267.

Ames, C. (1992). Classrooms: Goals, structuresa, and student motivation. Journal of Educational Psychology, 84(3), 261-271.

Antoniou, F. (2014). One for All or All for One? Do Principal's and Teacher's Goal Orientations Affect Students ${ }^{\text {ee }}$ Achievement in Reading, Spelling and Vocabulary? Procedia - Soc. Behav. Sci., 131, 484-490. DOI: 10.1016/j.sbspro.2014.04.153.

Arslan, A. (2011). Öğretmen adaylarının amaç yönelimleri ile yapılandırmacıllğa yönelik görüşlerinin incelenmesi. Ondokuг Mayıs Üniversitesi Eğitim Fakültesi Dergisi, 30(1), 107-122

Arslan, S. ve Akın, A. (2015). 2x2 Başarı Yönelimleri Ölçeği (Revize Formu): Geçerlik ve Güvenirlik Çalışması. Sakarya UniversityJournal of Education, 5(1),7-15.

Aydın, S. (2014). Öğretmen adaylarının başarı amaç yönelimleri ve akademik öz-yeterliklerinin yapısal eşitlik modeliyle incelenmesi. Electronic Turkish Studies, 9(2), 221-230.

Barron, K. E., Finney, S. J., Davis, S. L. \& Owens, K. M. (2003). Achievement Goal Pursuit: Are Different Goals Activated and More Beneficial in Different Types of Academic Situations? Paper presented at the Annual Meeting of theAmerican Educational Research Association, Chicago, April 21-25.

Bartels J. ve Magun-Jackson (2009). Approach- avoidence motivation and metacognitive self regulation: The role of need for achievement and fear of failure. Learning and Individual Differences, 19, 459463.

Buldur, S. (2014). Öğrencilerin sınıf-içi değerlendirme ortamına ilişkin algıları ile başarı amaç oryantasyonları arasındaki ilişkinin incelenmesi: Cinsiyet Perspektifi. Eg̈itim ve Bilim, 39(176), 213225.

Conroy, D. E., Elliot, A. J. ve Hofer, S. M. (2003). A 2 X2 achievement goals questionnaire for sport: Evidence for factorial invariance, temporal stability, and external validity. Journal of Sport and Exercise Psychology, 25, 456-476. 
Kösterelioğlu, İ., Çelen, Ü., Akın Kösterelioğlu, M., \& Ahıska, A. R. (2019). Lise öğrencilerinin başarı amaç yönelimleri. Journal of Human Sciences, 16(2), 662-678, doi: 10.14687/ihs.v16i2.5603

Dinç, Z. F. (2010). Relationship between Achievement Goal Orientation and Physical Self-perception among Students Attending Physical Education Teaching. World Applied SciencesJournal, 11(6), $662-$ 668.

Dweck. C. S. ve Leggett. E. L. (1988). A social-cognitive approach to motivation and personality. Psychological Review, 95(2), 256-273.

Elliot, A. J. (1999). Approach and avoidance motivation and achievement goals. Educational Psychologist, $34,169-189$.

Elliot, A. J. (2005). A conceptual history of the achievement goal construct. In A. J. Elliot\& C. S. Dweck (Eds.), Handbook of competence and motivation (pp. 52-72). New York, NY: Guilford Publications.

Elliot, A. J. ve Church, M. A. (1997). A hierarchical model of approach and avoidance achievement motivation. Journal of Personality and Social Psychology, 72, 218-232.

Elliot, A. J. ve Harackiewicz, J. M. (1996). Approach and avoidance achievement goals and intrinsic motivation: A mediational analysis. Journal of Personality and Social Psychology, 70, 461-475.

Elliot, A. ve McGregor, H. (2001). A 2x2 achievement goal framework. Journal of Personality and Social Psychology, 80, 501-519.

Finney, S. J., Pieper, S. L. ve Barron, K. E. (2004). Examining the psychometric properties of the Achievement Goal Questionnaire in a general academic context. Educationaland Psychological Measurement, 64, 365-382.

Freudenthaler, H. H., Spinath B. ve Neubauer A.C. (2008). Predicting school achievement in boys and girls. European Journal of Personality, 22(3), 231-245.

Green, B. A. ve Miller, R. B. (1996). Influences on Achievement: Goals, perceived ability, and cognitive engagement. Contemporary Educational Psychology, 21(2), 181-192.

Hanrahan, J. S. ve Cerin, E. (2009). Gender, level of participation, andtype of sport: Differences in achievement goal orientation and attributional style. Journal of Science and Medicine in Sport, 12 (2009), 508-512.

Harackiewicz, J. M., Durik, A. M., Barron, K. E., Linnenbrink-Garcia, L., ve Tauer, J. M. (2008). The role of achievement goals in thedevelopment of interest: Reciprocal relations between achievement goals, interest, and performance. Journal of Educational Psychology, 100, 105-122.

Hulleman, C. S., Durik, A. M., Schweigert, S. B. ve Harackiewicz, J. M. (2008). Task values, achievement goals, and interest: An integrative analysis. Journal of Educational Psychology, 100, 398-416.

Isoard-Gautheur, S., Guillet-Descas, E. ve Duda, J. L. (2013). How to achieve in elite training centers without burning out? An achievement goal theory perspective. Psychology of Sport and Exercise, 14, 72-83.

İzci, E. ve Koç, S. (2012). Pedogojik formasyon eğitimi alan öğrencilerin başarı yönelim düzeylerinin incelenmesi. Dicle Üniversitesi Sosyal Bilimler Enstitüsü Dergisi, 4(8), 31-43.

Kadıoğlu, C. ve Kondakçı, E. U. (2014). Relationship between learning strategies and goal orientations: A multilevel analysis. Eurasian Journal of Educational Research, 56, 1-22, http://dx.doi.org/10.14689/ejer.2014.56.4

Kaplan, A. ve Maehr, M. L. (1999). Achievement goals and student well-being. Contemporary Educational Psychology, 24(4), 330-358.

Küçükoğlu, A., Kaya, H. İ. ve Turan, A. (2010). Sınıf öğretmenliği ABD öğrencilerinin başarı yönelimi algılarının farklı değişkenler açısından incelenmesi (Atatürk Üniversitesi ve Ondokuz Mayıs Üniversitesi Örneği). Frrat Üniversitesi Sosyal Bilimler Dergisi, 20(2), 121-135.

Lemyre, P., Roberts, G. C. ve Ommundsen, Y. (2002). Achievement goal orientations, perceived ability, and sportspersonship in youth soccer. Journal of Applied Sport Psychology, 14, 120-136.

Meece, J. L., Blumenfeld, P. C. ve Hoyle, R. H. (1988). Students' Goal Orientations and Cognitive Engagement in Classroom Activities. Journal of Educational Psychology, 80, 514- 523.

Middleton, M. J., Kaplan, A. ve Midgley, C. (2004). The change in middle school students' achievement goals in mathematics over time. Social Psychology of Education, 7, 289- 311.

Murayama, K., Elliot, A. ve Yamagata, S. (2011). Separation of performance-approach and performanceavoidance achievement goals: A broader analysis. Journal of Educational Psychology, 103(1), 238-256. 
Kösterelioğlu, İ., Çelen, Ü., Akın Kösterelioğlu, M., \& Ahıska, A. R. (2019). Lise öğrencilerinin başarı amaç yönelimleri. Journal of Human Sciences, 16(2), 662-678, doi: 10.14687/ihs.v16i2.5603

Özgüngör, S. (2003). Mükemmeliyetçilik ve özerklik destekleyici davranışların amaç tarzları ile ilişkisi. Eg̈itim ve Bilim, 28(127), 25-30.

Özgüngör, S. (2014). Üniversite Öğrencilerinde Benlik Saygısı Düzeyine Göre Kimlik Statüleri ile Başarı Yönelimleri Arasındaki İlişki. Pamukkeale Üniversitesi Ë̈itim Fakültesi Dergisi, 35(1), 33-46.

Pajares, F. ve Cheong, Y. F. (2003). Achievement goal orientations in writing: A developmental perspective. International Journal of Educational Research, 39, 437-455.

Pekrun, R., Elliot, A. J. ve Maier, M. A. (2006). Achievement goals and discrete achievement emotions: A theoretical model and prospective test. Journal of Educational Psychology, 98, 583-597.

Pintrich, P. R. (2000). An achievement goal theory perspective on issues in motivation terminology, theory, and research. Contemporary Educational Psychology, 25, 92104.

Rawsthorne, L. J. ve Elliot, A. J. (1999). Achievement goals and intrinsic motivation: A meta-analytic review. Personality and Social Psychology Review, 3(4), 326-344.

Régner, I., Loose, F. ve Dumas, F. (2009). Students' perceptions of parental and teacher academic involvement: Consequences on achievement goals. EuropeanJournal of Psychology of Education, 14(2), 263-277.

Rosas, J. S. (2015). Validation of theAchievement Goal Questionnaire - Revised in Argentinean University Students (A-AGQ-R). Int.J.Psychol.Res., 8(1), 10-23

Schunk, D. H. (1996). Goaland self-evaluative influences during children's cognitive skill learning. American Educational Research Journal, 33, 359-382.

Schunk, D. H., Pintrich, P. R. ve Meece, J. L. (2008). Motivation in education: theory, research, andapplications (3rd ed.). UpperSaddleRiver, N.J. :Pearson/Merrill PrenticeHall.

Smith, L. ve Sinclair, K. E. (2005). Empirical evidence for multiple goals: A gender-based, senior high school student perspective. Australian Journal of Educational \& Developmental Psychology, 5, 55-70.

Soltaninejad, M. (2015). InvestigatingPredictive Role of 2x2 Achievement Goal Orientations on Learning Strategies with Structural Equation Modeling. The Malaysian Online Journal of Educational Science, 3(3), 21-30.

Wang, C. K. J., Liu, W. C., Lochbaum, M. R. ve Stevenson, S. J. (2009). Sport Ability Beliefs, 2 x 2 Achievement Goals, and Intrinsic Motivation. Research Quarterly for Exercise and Sport, 80(2), 303312. http://dx.doi.org/10.1080/02701367.2009.10599565

Wolters, C. A. (2004). Advancing Achievement Goal Theory: Using Goal Structures and Goal Orientations to Predict Students' Motivation, Cognition and Achievement. Journal of Educational Psychology, 96, 236-250. https://doi.org/10.1037/0022-0663.96.2.236.

\section{Extended English Summary}

\section{Introduction}

The purpose of instructional activities is to achieve the objectives of the curriculum. Achieving the objectives of the curriculum is associated with the term "success". Students follows different paths to obtain success. One of the theories which attempts to explains the means that are employed by students is Goal Orientation Theory. It dwells on motivations for success and the positive and negative behaviors displayed by the students, including active engagement to the courses and appreciating the learning as well as drop out and absenteeism (Schunk, Pintrich and Meece, 2008). Emerging evidence suggests that learners are often apt to adopt two tendencies as to academic motivation, such as mastery goal or performance goal orientation (Ames and Archer, 1988; Elliot and McGregor, 2001). This model, cited as Traditional Goal Orientation Model, underpins that learners who pursue academic behaviors in order to develop their skills and who assess their competence according to their self-improvement would be labeled as having a mastery goal orientation, whereas those with academic behaviors in order to display their skills and assess their competence according to others (Xiang, 2008) would be labeled as having a performance goal orientation (Agbuga and Xiang, 2008). In a nutshell, mastery goal orientation is related to having positive attitudes to being successful, learning, giving effort and competing with yourself. 
Kösterelioğlu, İ., Çelen, Ü., Akın Kösterelioğlu, M., \& Ahıska, A. R. (2019). Lise öğrencilerinin başarı amaç yönelimleri. Journal of Human Sciences, 16(2), 662-678, doi: 10.14687/ihs.v16i2.5603

Alternatively, performance goal orientation is concerned about the performance in relation to others, is focused on performing better than others and presumes that achievement can be reached via less efforts (Agbuga, 2014).

\section{Method}

This study employed a quantitative research method, designed as a descriptive one. The sample for the study was drawn fromstudents who study in Amasya Province of Turkey. There were 24449 students of whom were 12544 male and 11905 female students in 1062 classes according to Turkish Statistical Institute (TIS) data. Participation from 25 high schools in Amasya city out of a total of 63 schools in 2015-2016 education year was solicited. A class in each grade among the sampling schools was randomly recruited and data was obtained through data collection instruments in these randomly selected classes. The data collection instrument was submitted to 796 students. In order to obtain data, a questionnaire developed by the researcher and 2X2 Achievement Goal Orientations Scale, adopted to Turkish by Arslan and Akın (2015) were employed in order to collect data in the study. The scale encompassed 4 subdimensions with total of 26 items. Independent samples t-test was used to compare the means of two independent samples, while One-Way ANOVA was employed to make multiple comparisons. For evaluating differences among the groups, the least significance difference (LSD) method was employed. The chi-square test was applicable to while examining the relation between the variables based on a hypothesis.

\section{Findings}

Employing the statistical analysis, it was found that the mean score of the learning approach goal orientation subscale was the highest, whereas performance avoidance goal orientation was the lowest. Female participants had the highest scores in learning approach and learning avoidance goal orientations subscales, while the male counterparts had the highest scores in performance approach and performance avoidance subscales. The mean scores obtained from learning approach and learning avoidance goal orientations subscales didn't show any significant differences according to grade level, whereas a statistical significant difference was found in performance approach and performance avoidance subscales according to grade level. To determine whether the mean scores of the 4th grade students are significantly different from other grade levels, pairwise comparions were employed and it was found that the mean scores of the 4th grade students are lower than the other grades in both subscales. When it was evaluated in terms of school type, it was found that the mean scores of Religious Vocational and other vocational high school students had higher mean scores in learning approach and performance approach goal orientation subscales than the students attending Anatolian, Science and Social Sciences high schools. The mean scores of the vocational students, on the other hand, were higher than the scores of the students of the other type of high schools in the performance avoidance subscale. In the learning approach subscale, the mean scores of the students who perceived themselves as successful were higher than the others, while those who regarded themselves partly successful were higher than the students who were unsuccessful and partly unsuccessful. In the performance approach subscale, mean scores of the students considering themselves successful were higher than the other students. The percentage of the students regarding themselves as successful or partly successful in learning approach tendency was higher than the students considering themselves unsuccessful or partly unsuccessful. The percentage of the students regarding themselves as partly successful in learning avoidance and performance avoidance tendency was higher than percentage of the students who adopted a performance approach goal orientation motivation. 


\section{Result}

When the mean scores are evaluated, it can be mentioned that the mean score of the learning approach subscale is the highest, whereas that of performance avoidance is the lowest. Female students have higher scores in learning approach and learning avoidance goal orientations, while male counterparts have higher scores in performance approach and performance avoidance goal orientations. The goal orientation mean scores of learners don't show any significant differences in terms of grade level. When the scores of the learners according to school type are examined, it can be noted that there is no statistical difference in the learning avoidance subscale scores of the students and there is meaningful statistical difference in the other subscale mean scores. A statistical significant difference is found between the scores of success perceptions of the students and goal orientation tendency subscale.

\section{Recommendations}

The goal orientations of the students can be revealed through goal orientation questionnaires conducted by counselling services in schools. The obtained results can be shared with teachers so that they can know them well. Learner groups can be formed thanks to these analyses based on the goal orientations of the students. Activities can be designed to lead students to learning designed for learning approach and it helps students continue their motivation. Based on the findings of this present study, this paper is believed to serve as a base for future studies on in-depth interviews on the factors affecting the goal orientations of the students. 